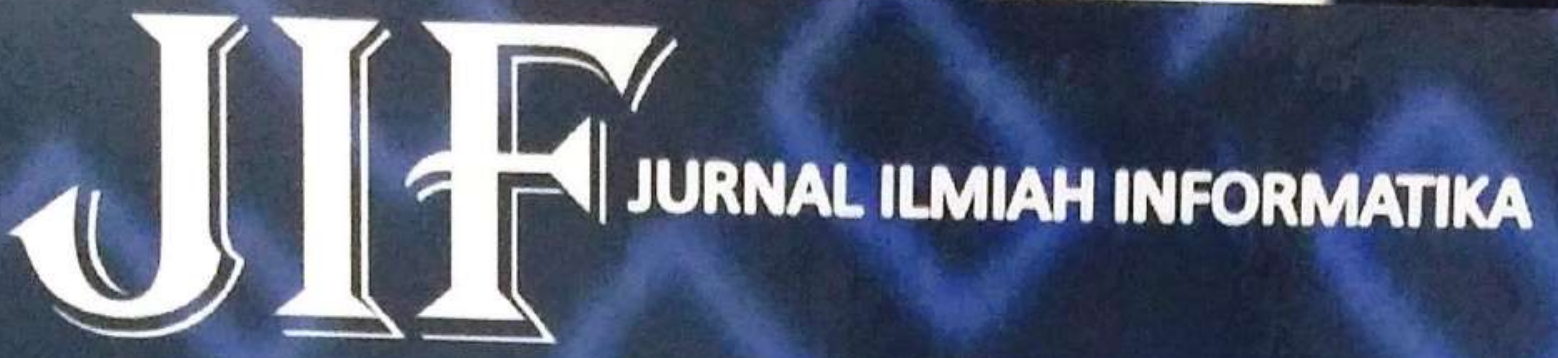

Volume 4, Nomor 1, Maret 2016

ANALISIS KOMPARATIF SISTEM KEAMANAN WINDOWS 7 DAN WINDOWS 8

Cosmas Eko Suharyanto

PERANCANGAN SISTEM PAKAR UNTUK MENDIAGNOSA PENYAKIT PARU-PARU MENGGUNAKAN THEOREMA BAYES DAN BERBASIS WEB

Koko Handoko

ANALISIS PERBANDINGAN KECEPATAN KONEKSI INTERNET DENGAN LAYANAN SPEEDY TELKOM PADA TAMAN HOTSPOT DI KOTA BATAM

Hotma Pangaribuan dan Kurnia Laiya

PREDIKSI JUMLAH PENUMPANG PESAWAT UDARA MENGGUNAKAN JARINGAN SYARAF TIRUAN METODE BACKPROPAGATION DI BANDAR UDARA HANG NADIM BATAM

Joni Eka Candra

IMPLEMENTASI DATA MINING PADA PENJUALAN BAHAN BANGUNAN DENGAN ALGORITMA FP-GROWTH Rahmat Fauzi

PENGEMBANGAN SISTEM INFORMASI PENGOLAHAN DATA LAYANAN SERVICE KENDARAAN PADA STEEL MOTOR PADANG DENGAN MENGGUNAKAN BAHASA PEMROGRAMAN JAVA YANG DIDUKUNG OLEH DATABASE MYSQL

Rahadian Aulia Firda

ANALISIS PEMANFAATAN SISTEM MENU DAN USABILITY SOFTWARE MY HOSPITAL DI RUMAH SAKIT BADAN PENGUSAHAAN (RSBP) BATAM

Nia Ekawati

SISTEM INFORAMASI PUBLIKASI YAYASAN RAUDHATUL MADINAH SAWAHLUNTO DENGAN MENGGUNAKAN BAHASÃ PEMROGRAMAN PHP DESAIN WEBSITE

Nanda Jarti

ANALISIS FUNGSI BORDA DALAM KEPUTUSAN PEMBELIAN LAPTOP (STUDI KASUS PADA SEKOLAH MENENGAH KEJURUAN SEKOTA BATAM)

Rika Harman

PERAN MEDIA PEMBELAJARAN BERBASIS TEKNOLOGI INFORMASI DALAM KEGIATAN BELAJAR MENGAJAR ( STUDI KASUS PADA SISWA KELAS XI SMA ANANDA BATAM)

Muhammad Taufik Syastra dan Steffi Adam 


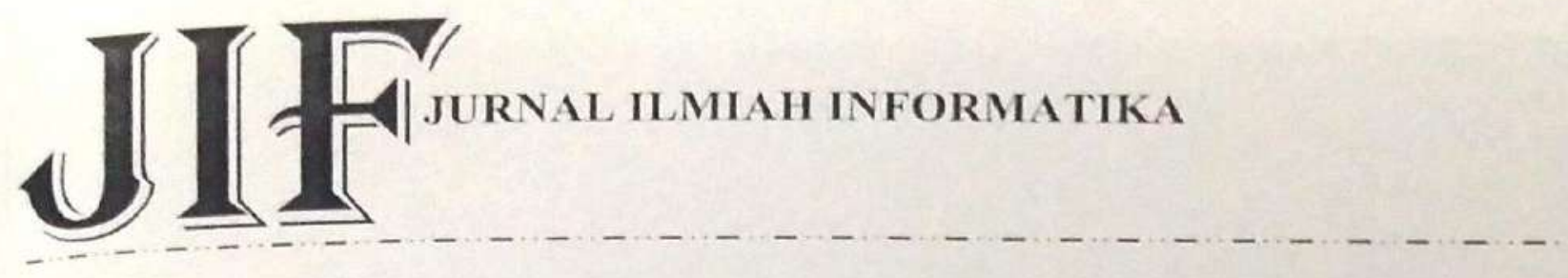

Volume 4 No. 1 Maret 2016

ISSN :2337-8379

Diterbitkan oleh

Pelindung

Penasehat

Penanggung Jawab

Ketua Penyunting

Anggota Penyunting

Ketua Redaksi Pelaksana

Anggota Redaksi

Editor

Layout \& Desain

Administrasi Umum
: LPPM Universitas Putera Batam

: Rektor Universitas Putera Batam

: Dekan Fakultas Teknik dan MIPA

Universitas Putera Batam

: Ketua Program Studi Teknik Informatika

Universitas Putera Batam

: Andi Maslan, S.T., M.SI

: Pastima Simanjuntak, S.Kom., M.SI

Fifi, S.Kom., M.SI

Firdaus Hamta, S.E., M.SI

: Realize,S.Kom., M.SI

: Nia Ekawati, S.Kom., M.SI

Rika Harman, S.Kom., M.SI

Drs. Zakrimal, M.SI

Desi Sariani, S.Pd., M.SI

: Hotma Pangaribuan, S.Kom., M.SI

Ganda Sirait, S.Si., M.SI

Said Thaha Ghafara, S.Kom., M.SI

: Tukino, S.Kom., M.SI

: Tiurniari, S.E., M.M

\section{Alamat Redaksi :}

Program Studi Teknik Informatika Fakultas Teknik dan MIPA Universitas Putera Batam

Jalan R. Soeprapto, Tembesi, MukaKuning-Batam

Telepon : $0778-7001000$

e-mail: t.inf@puterabatam.ac.id 
JIF (Jurnal Ilmiah Informatika) Vol.4 Nomor 1, Maret 2016

ISSN: $2337-8379$

\title{
Analisis Komparatif Sistem Keamanan Windows 7 Dan Windows 8
}

\author{
Cosmas Eko Suharyanto \\ Universitas Putera Batam, Batam 29434, Indonesia \\ Email: costmust@gmail.com
}

\begin{abstract}
The operating system is a vital part of the computer system. Windows users still occupies the top position in the operating system user statistics. The popular Windows operating system, Windows 7 and Windows 8 , they still have loyal users. The issue of information security becomes important with the increasing use of today's technology in various aspects. This study aims to analyze system security in Windows 7 and Windows 8 . The results of this study prove the security system of Windows 8 is superior to its predecessor Windows 7. However, the primacy of security system $W$ indows 8 can not be separated from some of notes that should be of concern to the user.
\end{abstract}

Keywords: information security, operating system, windows 7, windows 8

\section{Pendahuluan}

Komputer telah mengalami evolusi yang sangat cepat dan tidak bisa dibandingkan lagi seperti dulu ketika diperkenalkan. Tidak hanya untuk menyimpan data-data, melakukan operasi aritmatika, dan menjalankan aplikasi, namun sejalan dengan semakin meningkatnya performa hardware komputer, keberadaannya menjadi semakin vital dalam berbagai geliat aspek kehidupan dewasa ini. Salah satu bagian terpenting dalam sistem komputer adalah sistem operasi.

Pengguna sistem operasi Windows 7 masih menduduki posisi teratas selama tahun 2015 dengan ratarata di atas 50\% pengguna. Sedangkan penerusnya, Windows 8 , meskipun mengalami tren yang positif (naik), namun kenaikannya tidaklah signifikan [2]. Fungsi dari sistem operasi adalah mengorganisasi dan mengontrol hardware dan software sehingga keseluruhan sistem-sistem tersebut dapat bekerja sesuai dengan fungsinya dengan efisien, efektif, dan aman [3]. Berangkat dari vitalnya fungsi sistem operasi, maka kajian keamanan menjadi isu penting setelahnya.

Windows 8 mungkin lebih aman dibanding pendahulunya. Windows 8 mempunyai sistem keamanan saat booting, yang akan berhenti jika ada file-file inti mengalami masalah [4]. Windows 8 menyediakan perangkat lunak dan perangkat lainnya berdasarkan standar keamanan Microsoft, seperti backup system, windows change management, computer virus protection, physical access, system hardening, dan security monitoring [5]. Bagaimanakah jika dibandingkan dengan Windows 7 yang sampai saat ini masih mempunyai pengguna setia terbanyak? 


\section{Sistem Operasi}

Sistem operasi adalah program yang menutup detail hardware yang rumit kepada programmer dan menyediakan antarmuka yang lebih mudah bagi programmer untuk mengakses hardware dalam mengembangkan sebuah program [6]. Dengan kata lain, Sistem Operasi menjadi penghubung antara software aplikasi komputer dengan hardware, sehingga software aplikasi tersebut dapat mengakses bardwere dengan baik. Tanenbaum [6] mempertegas fungsi sistem operasi sebagai resource manager yaitu mengijinkan multiple program berjalan pada waktu yang sama, mengelola dan melindungi memori, $\mathrm{I} / \mathrm{O}$ devices, dan sumberdaya lainnya.

Sistem operasi mengalami perkembangan yang sangat pesat, yang dapat dibagi kedalam empat generasi [6]:

1. Generasi Pertama (1945-1955)

Generasi pertama merupakan awal perkembangan sistem komputasi elektronik sebagai pengganti sistem komputasi mekanik, hal itu disebabkan kecepatan manusia untuk menghitung terbatas dan manusia sangat mudah untuk membuat kecerobohan, kekeliruan bahkan kesalahan. Pada generasi ini belum ada sistem operasi, maka sistem komputer diberi instruksi yang harus dikerjakan secara langsung.

2. Generasi Kedua (1955-1965)

Generasi kedua memperkenalkan Batch Processing System, yaitu Job yang dikerjakan dalam satu rangkaian, lalu dieksekusi secara berurutan. Pada generasi ini sistem komputer belum dilengkapi sistem operasi, tetapi beberapa fungsi sistem operasi telah ada, contohnya fungsi sistem operasi ialah FMS dan IBSYS.

3. Generasi Ketiga (1965-1980)

Pada generasi ini perkembangan sistem operasi dikembangkan untuk melayani banyak pemakai sekaligus, dimana para pemakai interaktif berkomunikasi lewat terminal secara on-line ke komputer, maka sistem operasi menjadi multi-user (digunakan banyak pengguna sekaligus) dan multi-programming (melayani banyak program sekali gus).

4. Generasi Keempat (Pasca 1980an)

Dewasa ini, sistem operasi dipergunakan untuk jaringan komputer dimana pemakai menyadari keberadaan komputer-komputer yang saling terhubung satu sama lainnya. Pada masa ini para pengguna juga telah dinyamankan dengan Graphical User Interface yaitu antarmuka komputer yang berbasis grafis yang sangat nyaman, pada masa ini juga dimulai era komputasi tersebar dimana komputasi-komputasi tidak lagi berpusat di satu titik, tetapi dipecah dibanyak komputer sehingga tercapai kinerja yang lebih baik.

\section{Sistem Operasi Microsoft Windows}

\section{Windows 7}

Tidak seperti pendahulunya yang memperkenalkan banyak fitur baru, Windows 7 lebih fokus pada pengembangan dasar Windows, dengan tujuan agar lebih kompatibel dengan aplikasi-aplikasi dan perangkat keras komputer yang kompatibel dengan Windows Vista [7]. Presentasi Microsoft tentang 
Windows 7 pada tahun 2008 lebih fokus pada dukungan multi-touch pada layar, desain ulang taskbar yang sekarang dikenal dengan nama Superbar, sebuah sistem jaringan rumahan bernama HomeGroup, dan peningkatan performa [8].

Beberapa aplikasi standar yang disertakan pada versi sebelumnya dari Microsoft Windows, seperti Windows Calendar, Windows Mail, Windows Movie Maker, dan Windows Photo Gallery, tidak disertakan lagi di Windows 7, kebanyakan ditawarkan oleh Microsoft secara terpisah sebagai bagian dari paket Windows Live Essentials yang gratis. Windows 7 memiliki enam versi yang sama dengan Windows Vista. Hanya saja ada perbedaan nama, jika Windows Vista memiliki versi Business maka pada Windows 7 versi tersebut dinamakan Professional. Ke- enam versi Windows 7 adalah Windows 7 Ultimate, Windows 7 Professional, Windows 7 Enterprise, Windows 7 Home Premium, Windows 7 Home Basic, Windows 7 Starter.

Tabel 1 Rekomendasi Spesifikasi Minimal Windows 7

\begin{tabular}{|c|c|c|}
\hline Arsitektur & 32-bit & 64-bit \\
\hline Kecepatan prosesor & 1 GHz 32-bit & 1 GHz 64-bit \\
\hline (RAM) & 1 GB & 2 GB \\
\hline Unit pengolah grafis & $\begin{array}{c}\text { Pengolah grafis dengan dukungan DirectX 9 dan WDDM Driver Model 1.0 } \\
\text { (tidak terlalu diperlukan, hanya dibutuhkan untuk Windows Aero) }\end{array}$ \\
\hline Hard disk (HDD) & Minimal 16 GB & Minimal 20 GB \\
\hline Drive Room & \multicolumn{2}{|c|}{ DVD drive (untuk instalasi dari media DVD) } \\
\hline
\end{tabular}

\section{Windows 8}

Microsoft secara resmi merilis Windows 8 pada 26 Oktober 2012 bersamaan dengan peluncuran komputer perdana yang menggunakan Windows 8. Windows 8 adalah nama dari versi terbaru Microsoft Windows, serangkaian sistem operasi yang diproduksi oleh Microsoft untuk digunakan pada komputer pribadi, termasuk komputer rumah dan bisnis, laptop, netbook, tablet PC, server, dan PC pusat media.

Antarmuka penggunanya diubah agar mampu digunakan pada peralatan layar sentuh selain mouse dan keyboard, sehingga Windows 8 di desain untuk perangkat tablet sentuh. Versi percobaan Windows 8 berupa Consumer Preview dan Release Preview. Pada 26 Juni 2013, Microsoft merilis versi Uji Coba dari Windows 8.1 (sebelumnya dikenal sebagai Windows Blue), sebuah peningkatan untuk Windows 8, Windows 7, Windows Vista, dan Windows XP. Pada 18 Oktober 2013, Microsoft merilis Windows 8.1 sebagai pembaruan gratis untuk Windows 8 .

Windows 8 tersedia dalam empat edisi : satu bernama hanya Windows 8, ditujukan untuk konsumen mainstream. Windows 8 Pro berisi fitur tambahan ditujukan untuk pengguna ahli dan lingkungan profesional. Windows 8 Enterprise mengandung fitur tambahan ditujukan terhadap lingkungan 
bisnis, dan hanya tersedia melalui pelisensian volume.Windows RT hanya tersedia yang sudah terinstall secara pabrikan pada perangkat baru berbasis ARM dan dibangun khusus untuk OS. Windows Media Center tidak disertakan secara default dalam setiap edisi Windows 8, tetapi tersedia untuk dibeli sebagai add-on untuk Windows 8-Pro, atau sebagai bagian dari "Pro Pack" upgrade untuk versi dasar Windows 8 yang juga termasuk Pro upgrade. Windows Media Center add-on yang ditawarkan secara gratis sampai dengan 31 Januari 2013.

Tabel 2 Rekomendasi Spesifikasi Minimal Windows 7

\begin{tabular}{|c|c|c|}
\hline Kriteria & Minimal & Direkomendasikan \\
\hline Arsitektur & $\mathbf{x 8 6 ~ ( 3 2 - b i t ) ~}$ & x86-64 (64-bit) \\
\hline Prosesor & $1 \mathrm{GHz}(\mathrm{x} 86)$ & $1 \mathrm{GHz}(\mathrm{x} 86-64)$ \\
\hline Memori (RAM) & $1 \mathrm{~GB}$ & $2 \mathrm{~GB}$ \\
\hline Kartu grafis & Prosesor grafis DirectX 9 atau yang lebih tinggi dengan driver WDDM \\
\hline $\begin{array}{c}\text { Ruang kosong } \\
\text { HDD }\end{array}$ & $16 \mathrm{~GB}$ & $32 \mathrm{~GB}$ \\
\hline
\end{tabular}

\section{Keamanan Sistem Operasi}

Informasi adalah aset, sebagaimana aset-aset penting lainnya, yang esensial terhadap bisnis organisasi dan oleh sebab itu perlu dilindungi dengan sepantasnya. Lebih penting lagi karena makin bertambahnya interkoneksi lingkungan bisnis. Sebagai dampak dari meningkatnya konektivitas, informasi diekspos terhadap ancaman dan vulnerability yang semakin hari semakin meningkat.

Garfinkel mengemukakan bahwa keamanan komputer melingkupi empat aspek, yaitu: privacy, integrity, authentication dan availability. Selain itu masih ada dua aspek lain yang juga sering dibahas dalam kaitannya dengan electronic commerce yaitu access control dan non repudiation [9].

1. Privacy atau Confidentiality: Inti utama dari aspek ini adalah usaha untuk menjaga informasi dari orang yang tidak berhak mengakses. Privacy lebih kearah data-data yang sifatnya pribadi, sedangkan confidentiality biasanya berhubungan dengan data yang diberikan ke pihak lain untuk keperluan tertentu.

2. Integrity: Aspek ini menekankan bahwa informasi tidak boleh diubah tanpa seizin pemilik informasi. Adanya virus, Trojan Horse atau pemakai lain yang mengubah informasi tanpa izin merupakan contoh yang harus dihadapi. Sebuah e-mail dapat saja ditangkap (intercept) ditenah jalan, diubah isinya (altered, tampered, modified) kemudian diteruskan kealamat yang dituju. Contoh serangan lain adalah yang disebut "Man In The Midle Attack" dimana seorang menempatkan diri ditengah pembicaraan dan menyamar sebagai orang lain.

3. Authentication: Aspek ini berhubungan dengan metode untuk menyatakan bahwa informasi betul-betul asli, orang yang mengakses atau memberikan informasi adalah betul-betul orang yang dimaksud, atau server yang kita tuju adalah benar-benar server asli. Dalam hal ini 
pengguna harus menunjukkan bukti bahwa memang dia adalah pengguna yang sah, misalnya dengan menggunakan password, keamanan biometric dan sejenisnya.

4. Availability: Aspek availability atau ketersediaan berhubungan dengan ketersediaan informasi ketika dibutuhkan. Sistem informasi yang diserang dapat menghambat akses keinformasi. Contoh hambatan adalah serangan yang sering disebut dengan "denial of service attact" dimana server dikirimi permintaan palsu yang bertubi-tubi atau permintaan yang diluar perkiraan sehingga tidak dapat melayani permintaan lain dan bahkan sampai down, hang serta crash.

\section{NIST- SP800-115}

National Institute of Standard and Technology (NIST) telah mengeluarkan standar metodologi untuk melakukan pengujian keamanan sistem. Disain itu dipublikasikan dalam Special Publication 800-115 [10]. Tujuan dari publikasi ini adalah untuk memberikan pedoman untuk perencanaan organisasi, pelaksanaan dan evaluasi pengujian keamanan informasi. Tujuan secara menyeluruhnya adalah untuk mengusulkan gambaran elemen kunci utama penilaian keamanan teknis.

NIST mendefinisikan security assesment sebagai proses menentukan bagaimana keefektifan sebuah entitas apakah memnuhi dengan tujuan keamanan tertentu. Oleh karena itu secara umum ada tiga cara yang dapat dilakukan untuk mencapai target tersebut:

1. Melalui testing, yaitu dengan memeriksa objek penilaian; membandingkan perilaku aktual dengan yang diharapkan

2. Melalui examination, dengan menganalisis obyek penilaian dan memahami fungsi mereka

3. Melalui interviewing, dengan melakukan diskusi yang mendalam dengan organisasi dan para ahli untuk mengidentifikasi kemungkinan masalah

Metodologi yang dibuat oleh NIST ini terdiri dari 3 fase umum, yaitu: perencanaan (planning), eksekusi (execution), dan pasca eksekusi (post execution). Pada fase perencanaan, fase ini diperlukan untuk mengumpulkan semua informasi yang diperlukan untuk penilaian. Hal ini menyangkut unsurunsur seperti aset, ancaman, kebijakan digunakan, dll. Selain itu, penilaian harus memiliki tujuan akhir dan serangkaian tujuan lain untuk dikerjakan kemudian. Fase eksekusi, fase ini menyangkut bagian operasional penilaian. Fase eksekusi mengimplementasikan operasi analisis dan penemuan lingkungan sistem, kerentanan sistem, dan validasi hasil. Kegiatan praktis untuk fase ini jelas berbeda dari kasus ke kasus. Namun, tujuan utama adalah untuk membawa masalah ke tingkat teknis dan organisasi.

Fase paska eksekusi, fase ini menjelaskan semua tujuan analisis dengan mengidentifikasi penyebab kerentanan dan strategi mitigasi. Pengembangan laporan akhir adalah output utama dari fase pasca eksekusi. Secara keseluruhan, NIST SP800-115 juga menyediakan pendekatan yang terstruktur dan lengkap yang masuk ke detail teknis lebih dari metodologi lainnya (OSSTMM, OSSAF). 


\section{Analisis dan Pembahasan}

\section{Sistem Keamanan pada Sistem Operasi Windows 7}

Sebagai pengganti dari Windows Vista, Windows 7 mengusung berbagai fitur yang membuatnya lebih unggul di berbagai bidang, termasuk keamanan sistem. Windows 7 Ultimate merupakan edisi Windows 7 yang memiliki fitur yang lengkap. Berikut ini adalah fitur keamanan pada Windows 7 :

\section{1) Action Center}

Action Center merupakan sebuah fitur Windows 7 yang digunakan untuk memonitor setiap aktivitas Windows 7 terkait dengan keamanan (security) dan pemeliharaan (maintenance). Jika ada masalah terkait dengan security atau maintenance dan Windows 7 menganggapnya sebagai suatu hal yang harus diperhatikan, maka melalui notification area yang terdapat di taskbar, Action Center akan mengirim sebuah sinyal dan memberikan sebuah solusi yang dianggap mampu mengatasi masalah yang dihadapi. Sinyal yang diberikan oleh Action Center ditandai dengan dua warna, yaitu merah dan kuning. Sinyal yang berwarna merah merupakan sebuah pesan yang sangat penting untuk diperhatikan dan dicarikan solusinya. Sinyal warna kuning digunakan untuk meminta mempertimbangkan sebuah solusi bagi penanganan masalah yang dijumpai.

\section{2) Windows Firewall}

Windows Firewall merupakan fitur yang berfungsi untuk menghadang setiap penyusup yang mencoba memasuki sistem Windows 7. Penyusup ini umumnya disebut hacker atau cracker. Umumnya pada hacker melakukan penyusupan ke sistem komputer untuk menguji pertahanan keamanan sebuah sistem, disamping menguji kemampuannya sendiri dalam menjebol pertahanan sistem operasi. Namun ada juga backer yang sengaja menyusup ke sistem komputer dengan tujuan mendapatkan informasi-informasi penting, seperti username, password, data bank dan bahkan rahasia-rahasia lainnya yang tersimpan di komputer. Hacker jenis ini sangat berbahaya jika dibiarkan bergerak dengan leluasa. Pada Windows 7, fitur yang berfungsi untuk menangkis serangan penyusup dikenal dengan sebutan Windows Firewall. Windows Firewall akan memonitor setiap informasi masuk ke komputer dan mencegah atau membolehkannya memasuki komputer seuai dengan pengaturan (setting) yang dilakukan. Windows Firewall dapat menangkis serangan hacker atau program-program penyerang lainnya sehingga data pribadi kita akan aman.

\section{3) Windows Defender}

Windows Defender merupakan sebuah program antispyware yang disediakan oleh Windows 7 secara gratis. Antispyware bawaan Windows 7 ini semakin menobatkan Windows 7 sebagai sistem operasi yang lebih aman dari sistem operasi Windows versi-versi terdahulu. Dengan mengaktifkan Windows Defender di Windows 7, sistem komputer akan mampu mencegah dan melawan setiap aksi teror yang dihadirkan oleh spyware atau program-program lain yang tidak diinginkan. Dengan melakukan update sistem secara berkala, maka kemampuan Windows Defender ini pun semakin handal dan sangat dapat dipercaya untuk melindungi komputer. 
Sistem ini juga mendukung Real-time protection yang dimilikinya yang akan memonitor setiap gerakan spyware atau program-program yang tidak diinginkan secara terus-menerus. Windows Defender juga mampu melakukan scanning terhadap komputer untuk memastikan tidak ada spyware-spyware yang ada di dalam media penyimpanan.

\section{4) User Account Control (UAC)}

User Account Control (UAC) merupakan sebuah fitur yang digunakan sebagai sistem kontrol Windows 7. UAC akan memantau terus menerus setiap gerakan pengguna komputer dan ketika dilakukan sebuah aksi yang berdampak pada sistem, maka UAC akan mengkonfirmasi izin akses yang dimiliki oleh pengguna tersebut. Dalam sistem Windows 7, hanya pengguna level administrator yang bebas melakukan perubahan apapun pada sistem komputer (meskipun perubahan tersebut membahayakan sistem). Sebagai contoh adalah ketika instalasi sebuah aplikasi atau program ke komputer. Proses instalasi ini memerlukan izin akses setingkat administrator, jadi jika menggunakan komputer dengan standard user account, maka tidak dapat melakukan proses instalasi program.

\section{5) Parental Control}

Parental Controls adalah sebuah fitur dari Windows 7 yang digunakan untuk mengatur dan memonitor cara anak dalam menggunakan komputer. Untuk menggunakan fitur ini, harus masuk sebagai administrator, dan batasan-batasan atau pengaturan yang dibuat pada parental controls hanya dapat diterapkan pada pengguna dengan user account bertipe standar. Ini artinya, untuk mengatur cara anak-anak menggunakan komputer, harus dibuatkan standar user account untuknya. Fitur yang sangat membantu para orang tua ini sudah hadir pertama kali sejak sistem operasi Windows Vista dirilis oleh Microsoft dan masih dipertahankan pada Windows 7. Dengan fitur ini, meskipun tidak berada di samping anak ketika mengoperasikan komputer, waktu penggunaan komputer dapat diatur, termasuk juga memblokir akses program tertentu dan juga mengatur serta memonitor cara anak-anak dalam menggunakan internet.

\section{6) Windows Update}

Windons update memeriksa update yang diberikan oleh Microsoft untuk memberi patch atau menambal celah pada Windows 7. Kenapa ini menjadi penting? Karena selain pengguna Microsoft Windows di seluruh dunia sangat luas, juga intensitas penggunaan internet yang meningkat sehingga memungkinkan terjadinya pemanfaatan bug dari pihak yang tidak bertanggung jawab untuk merusak sistem operasi. Ada dua macam jenis update pada Windows 7, yaitu Important Updates dan Optional Updates. Important Updates merupakan update yang bersifat penting untuk menambal celah pada Windows 7, sedangkan Optional Updates merupakan update yang tidak wajib Anda tambahkan karena biasanya pengaruh pada sistem tidak begitu besar. Update Windows biasanya dilakukan secara bertahap. Setelah update yang pertama, akan ada lagi update selanjutnya dan begitu seterusnya sampai keberadaan celah menjadi seminimal mungkin di Windows 7. 


\section{Sistem Keamanan pada Sistem Operasi Windows 8}

Setelah menganalisis fitur keamanan pada sistem operasi windows 7, sekarang mari kita lihat fitur keamanan pada sistem operasi Windows 8. Secara umum, firur dasar kemanan pada Windows 8 sama dengan dengan Windows 7, perbedaannya terletak pada tambahan-tambahan kemampuan dalam setiap fiturnya.

\section{1) Action Center}

Pada Windows 7, Windows Security Center telah berganti nama menjadi Action Center (sebelumnya disebut Windows Solution Center dan Windows Health Center). Ini dirancang untuk memusatkan dan mengurangi jumlah pemberitahuan tentang sistem; dengan demikian, sistem akan bertanggungjawab baik keamanan dan pemeliharaan komputer. Ikon pemberitahuan pada Windows Taskbar hanya muncul ketika ada pesan untuk diteliti dan ini menggantikan lima ikon pemberitahuan terpisah yang ditemukan di Windows Vista. Dalam pada Windows 8, Action Center memonitor 10 item baru: Microsoft account, Windows activation, SmartScreen, automatic maintenance, drive status, device software, startup apps, HomeGroup, File History, dan Storage Spaces.

\section{2) Windows Firewall}

Pada dasarnya tidak ada perubahan signifikan Windows Firewall pada Windows 8 dibandingkan dengan Windows 7. Windows Firewall memberikan 3 pilihan profil yaitu Home Network, Work Network dan Public Network. Home dan Work Network diklasifikasikan sebagai private network dimana kondisi jaringan dinilai relatif aman. Dengan memilih opsi "Home Network", kita bisa membuat Homegroup dimana network discovery akan dihidupkan dan membuat kita bisa melihat komputer lain yang terhubung dengan Network yang sama dengan kita.

Bergabung dengan Homegroup akan membuat komputer yang terkoneksi dapat me-share gambar, musik, video dan dokumen maupun sharing Printer. Bila ada folder yang ada di libraries kita yang tidak ingin di-share dapat dipilih untuk tidak di-share. Jika memilih "Work network", network discovery akan hidup secara default tapi kita tidak akan bisa membuat atau bergabung ke dalam Homegroup. Bila kita bergabung ke Domain Windows dan telah berhasil diautentifikasi, secara otomatis Windows Firewall akan mengenalinya dan mengklasifikasikan sebagai domain network. Public Network merupakan pilihan yang tepat bila kita sedang mengakses internet di area publik seperti restoran, kafe, ataupun saat memakai koneksi dengan internet melalui handphone. Memilih Public Network akan membuat setting Network Discovery off secara default sehingga komputer lain di jaringan tidak bisa melihat keberadaan anda dan pilihan profil ini akan membuat anda tidak bisa membuat atau bergabung kedalam bomegroup. 


\section{3) Windows Defender}

Berbeda dengan Windows 7, pada Windows 8 kemampuan Windows Defender mampu menggantikan Microsoft Security Essentials yang umumnya di-install pada Windows 7. Windows Defender berjalan di balik layar dan memberitahu ketika harus mengambil tindakan tertentu. Namun, sistem ini dapat dipergunakan kapan saja untuk memindai malware jika komputer tidak bekerja dengan baik atau ketika mengklik link yang mencurigakan pada saat online atau dalam pesan email. Windows Defender biasanya akan menghapus virus secara otomatis. Namun, dalam beberapa kasus, mungkin perlu menghapus virus secara manual. Ini bisa menjadi proses teknis yang harus dilakukan jika telah kehabisan semua opsi lain, maupun juga dengan registry Windows, untuk melihat dan menghapus sistem dan program file di Windows.

\section{4) User Account Control (UAC)}

Sama seperti pada Windows 7, User Account Control (UAC) dapat membantu mencegah perubahan tidak sah terhadap komputer. UAC akan memberitahu jika ada perubahan yang akan dibuat pada komputer yang memerlukan izin setingkat administrator. Jenis perubahan dapat mempengaruhi keamanan komputer atau dapat mempengaruhi pengaturan untuk orang lain yang menggunakan komputer. Dalam setingan bawaan Windows, pengaktifan UAC dapat membantu membuat komputer menjadi aman.

\section{5) Family Safety}

Fitur Parental Controls pada Windows 7 telah berubah menjadi Family Safety pada Windows 8. Dari segi fungsi tidak ada perbedaan yang signifikan, fitur ini digunakan untuk membantu melindungi keluarga dalam menggunakan komputer untuk berbagai kepentingan. Kita dapat membuat akun untuk anak-anak dan mengaktifkan pemantauan Family Safety, pilih batas tambahan dan izin yang ingin anak-anak memiliki, dan menafsirkan laporan kegiatan tentang penggunaan PC mereka dengan percaya diri. Dengan Windows 8, kita dapat memonitor apa yang anak lakukan, tidak peduli di mana mereka menggunakan PC mereka. Yang harus dilakukan adalah membuat account pengguna Windows untuk setiap anak, centang kotak untuk mengaktifkan Family Safety, dan kemudian meninjau laporan mingguan yang menggambarkan penggunaan PC anak-anak kita. Tidak ada download tambahan, instalasi, atau langkah-langkah konfigurasi yang diperlukan. Hanya memeriksa kotak.

\section{6) Windows Update}

Sama seperti pada Windows 7, Windows Update adalah layanan yang disediakan oleh Microsoft yang menyediakan update untuk sistem operasi Microsoft Windows dan komponen terpasang, termasuk Internet Explorer. Sebuah fitur opsional menonaktifkan akses ke Windows Update dan menggantikannya dengan akses ke Microsoft Update, versi yang diperluas dari layanan yang menyediakan update bukan hanya untuk sistem operasi dan Internet Explorer, tetapi juga untuk perangkat lunak lain berjalan di bawah Microsoft Windows, seperti Microsoft Office, aplikasi Windows Live, dan Microsoft Expression Studio. Update 
JIF (Jurnal Ilmiah Informatika) Vol.4 Nomor 1, Maret 2016

ISSN: $2337-8379$

biasanya disediakan melalui koneksi internet, meskipun ada ketentuan untuk update harus diinstal pada komputer tanpa koneksi internet.

\section{Pengujian Sistem dengan Standar NIST-SP800-115}

National Institute of Standards and Technology (NIST) mengembangkan dokumen ini sebagai kelanjutan dari tanggung jawab hukum di bawah Federal Information Security Management Act (FISMA) tahun 2002, Hukum Publik 107-347. Dengan adanya standar ini maka prosedur dan dokumen tentang pengujian sistem telah dilegitimasi secara luas dan dapat digunakans sebagai panduan apabila akan melakukan pengujian keamanan sistem. Berikut tahap-tahap yang dilalui :

\section{1) Review Techniques}

Langkah ini adalah mendefinisikan bagaimana memeriksa dan menganalisis kebijakan keamanan (Windows 7 dan Windows 8). Review Techniques menggambarkan proses pasif mengumpulkan informasi yang berkaitan dengan organisasi dan konsekwensi operasi analisis. Informasi ini termasuk kebijakan dan peralatan yang dipakai (sistem, jaringan, dsb). Teknik ini terdiri dari beberapa hal, yaitu document review, log review, ruleset review, system configuration review dan network monitoring. Karena teknik ini pasif, maka tidak mengganggu operasional dan sistem perusahaan. Untuk alasan ini, biasanya ini adalah tahap pertama dalam setiap penilaian keamanan. Oleh karena pada penelitian ini tidak dilakukan pada sebuah perusahaan, maka peneliti melewati tahap ini.

\section{2) Target Identification and Analysis Techniques}

Tahap ini fokus pada identifikasi perangkat aktif melalui port yang terbuka dan layanan yang berjalan dan menganalisis mereka mencari kerentanan. NIST SP800-115 membahas beberapa teknik di erent milik kelompok ini, yakni Network Discovery, Network Port and Service Identi cation, dan Vulnerability Scanning. Dari ketiga teknik ini, kedua teknik pertama tidak diaplikasikan untuk suatu host, oleh karena itu peneliti akan melakukan teknik ke tiga yaitu Vulnerability Scanning pada sistem operasi Windows 7 dan Windows 8.

\section{3) Vulnerability Scanning}

\section{Vulnerability Scanning pada Windows 7}

Pada penelitian ini menggunakan dua buah tool untuk melakukan scanning, tool yang digunakan adalah Microsoft Baseline Security Analyser dan Tripwire SecureCheq. Windows 7 yang di scan dalam keaadaan seting default paska instalasi.

a) Hasil Vulnerability Scanning Windows 7 dengan Microsoft Baseline Security Analyser Dalam scanning, terdapat vulnerability yaitu administrative vulnerabilities terdapat beberapa temuan, diantaranya yang bersifat critical, yaitu kelemahan Windows 7 yang mengijinkan blank password untuk user account, yang ke dua sistem mengijinkan automatic update untuk dimatikan dan critical yang ke tiga sistem mengijinkan membuat guest account untuk seseorang yang tidak bisa masuk ke sistem. 
JIF (Jurnal Ilmiah Informatika) Vol.4 Nomor 1, Maret 2016

ISSN: $2337-8379$

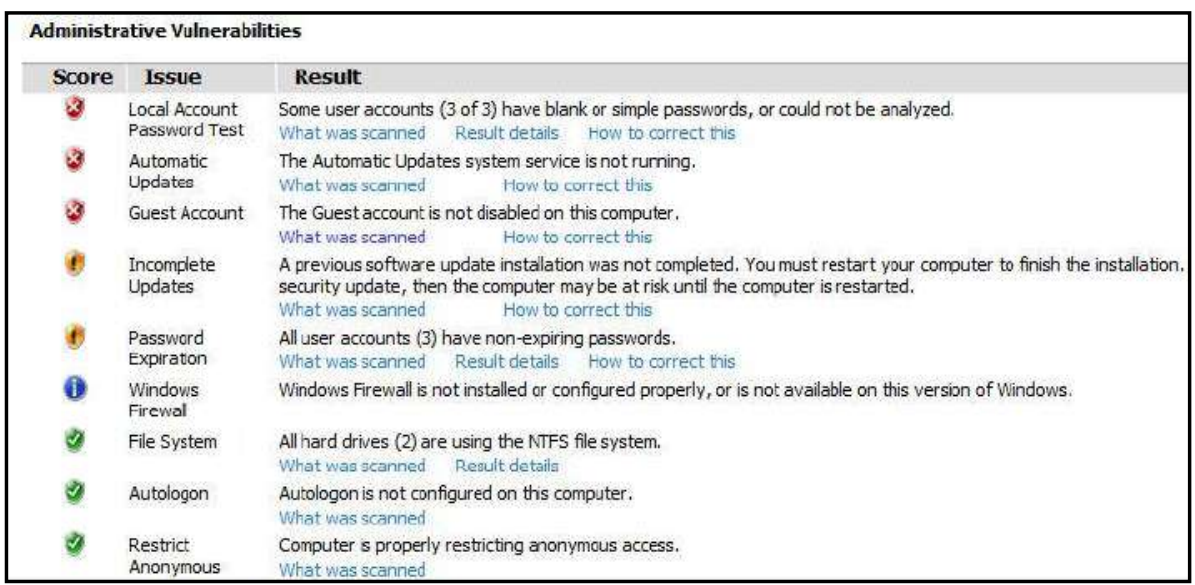

Gambar 1 Windows 7 Administrative Vulnerabilities

b) Hasil Vulnerability Scanning Windows 7 dengan Tripwire SecureCheq

Temuan dengan menggunakan tool Tripwire SecureCheq diantaranya adalah pada OS Hardening. Terdapat tiga vulnerabilities, yaitu dua kerentanan pada seting remote dekstop dan pada file dll pada sistem operasi.

\section{OS HARDENING}

Weak operating system configurations are exploited by attackers to gain access to machines and escalate privileges. Securing $0 S$ configurations will reduce or remove these avenues of attack.

This is part of SANS Critical Control 3. Secure Configurations for Hardware and Software on Mobile Devices, Laptops. Workstations, and Servers

\begin{tabular}{l|l} 
FAILED & Windows Remote Desktop Configured to Only Allow System
\end{tabular} Administrators Access

FAILED Windows Remote Desktop Configured to Always Prompt for Password

FAILED Safe DLL Search Mode is Enabled

\section{Gambar 2 Windows 7 OS Hardening}

Selanjutnya pada Data Protection terdapat satu vulnerability yaitu sama pada temuan dengan tool MBS; pada akun guest yang tidak di disabled.

\section{DATA PROTECTION}

Access to sensitive data is the goal of many attacks. Enforcing access controls around data is a solid first step in preventing data loss.

This is part of SANS Critical Control 15: Controlled Access Based on the Need to Know and SANS Critical Control 17: Data Loss Prevention

Passed

Passed

FAILED
Anonymous Access to Windows Shares and Named Pipes is Disallowed

All Shares are Configured to Prevent Anonymous Access

Windows Default Guest Account is Disabled 


\section{Gambar 3 Windows 7 Data Protection}

Pada user account security terdapat empat vulnerabilities, yaitu sistem yang mengijinkan penggunaan password yang lemah, tidak ada batas minimum penggunaan jumlah karakter/huruf/simbol yang dipakai untuk membuat password dan tidak adanya automatic lockout jika sistem ditinggalkan idel dalam beberapa saat.

\section{USER ACCOUNT SECURITY}

Legitimate user accounts are often exploited by attackers to gain access to sensitive systems and hide their tracks. Strengthening user account security helps protect against these attacks.

This is part of SANS Critical Control 16: Account Monitoring and Control and many other security frameworks.

\begin{tabular}{l|l} 
FAILED & Windows Password Complexity is Enabled
\end{tabular}

FAILED $\quad$ Minimum Windows Password Length Configured to be at Least 8 Characters

FAILED Windows Account Lockout Counter Configured to Wait at Least 15 Minutes Before Reset

FAILED Windows Account Lockout Duration Configured to at Least 15 Minutes

Gambar 4 Windows 7 User Account Security

\section{Vulnerability Scanning pada Windows 8}

Dengan metode yang sama, berikut ini hasil analisis pada Windows 8:

a) Hasil Vulnerability Scanning Windows 8 dengan Microsoft Baseline Security Analyser Dengan menggunakan tool yang sama, terdapat perbedaan hasil antara vulnerability pada Windows 7 dan Windows 8. Pada Windows 7 sebelumnya ditemukan tiga critical vulnerabilities, namun pada scanning Windows 8 tidak ditemukan adanya critical vulnerabilities. 
JIF (Jurnal Ilmiah Informatika) Vol.4 Nomor 1, Maret 2016

ISSN: $2337-8379$

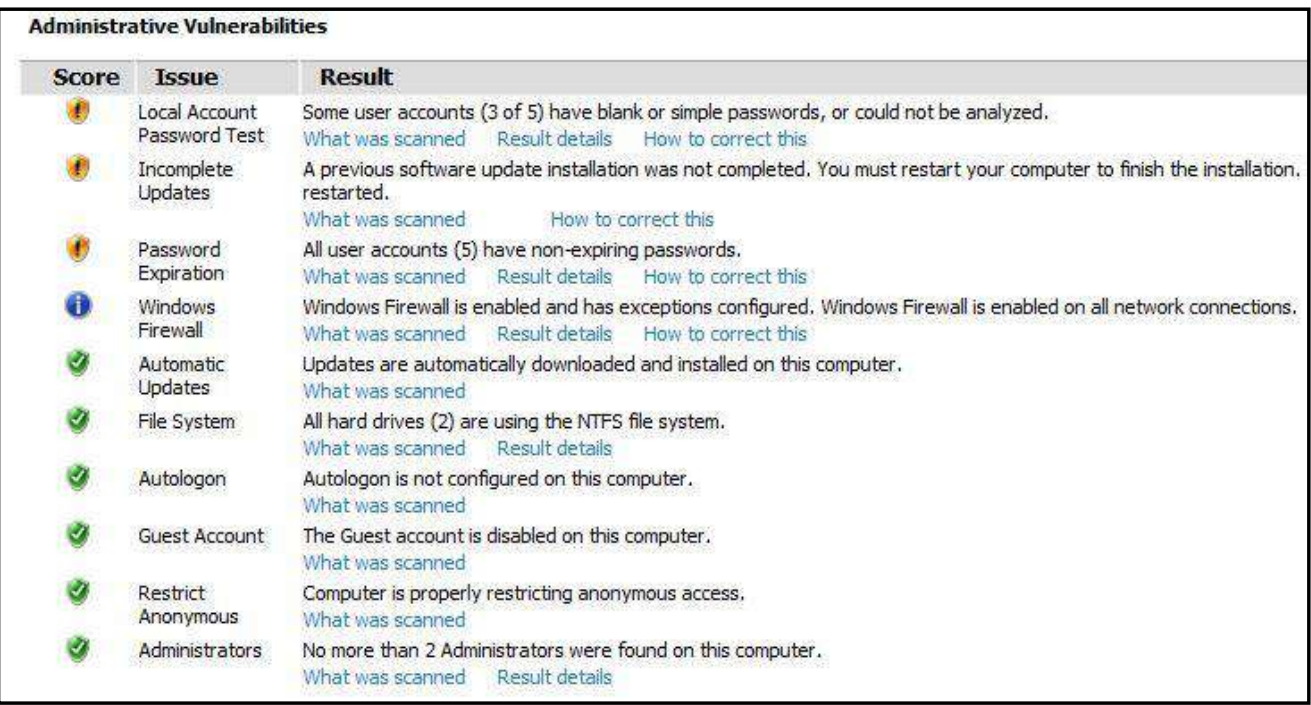

\section{Gambar 5 Windows 8 Administrative Vulnerabilities}

b) Hasil Vulnerability Scanning Windows 8 dengan Tripwire SecureCheq Scanning selanjutnya adalah menggunakan Tripwire SecureCheq. Pada tahap OS Hardening ditemukan vulnerabilities yang sama pada Windows 7 yaitu yaitu dua kerentanan pada seting remote dekstop dan pada file dll pada sistem operasi.

\begin{tabular}{|c|c|}
\hline \multicolumn{2}{|c|}{ OS HARDENING } \\
\hline \multicolumn{2}{|c|}{ 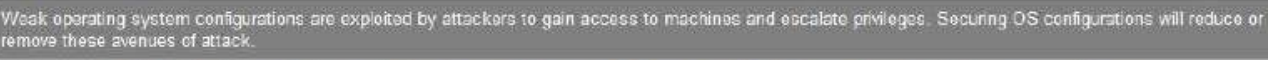 } \\
\hline \multicolumn{2}{|c|}{ This is part of SANS Critical Control 3 Socure Configurations for Hardware and Sctware on Nobilo Dovices. Laptops, Workotationa, and Senvera } \\
\hline FAILED & Windows Remote Desktop Configured to Only Allow System Administrators Access \\
\hline FAILED & Windows Remote Deskiop Configured to Always Prompt for Pas sword \\
\hline FAlLED & Safe DLL Search Mode is Enabled \\
\hline
\end{tabular}

\section{Gambar 6 Windows 8 OS Hardening}

Namun pada Data Protection, tidak ditemukan adanya vulnerability pada Windows 8, berbeda dengan Windows 7 yang ditemukan satu vulnerability.

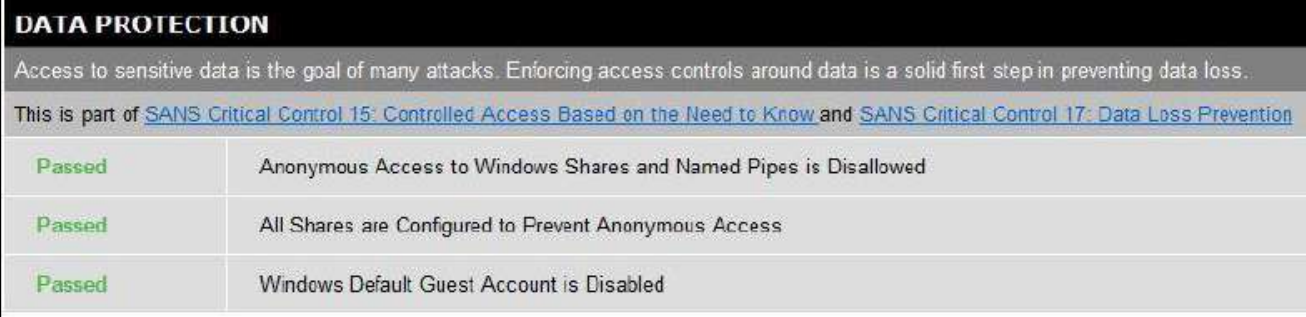

Gambar 7 Windows 8 Data Protection 
Selanjutnya pada tahap scanning user account security, terdapat kesamaan hasil dengan Windows 7, yaitu terdapat empat vulnerabilities terutama pada perlakuan password dan manajemen user account.

\begin{tabular}{|c|c|}
\hline \multicolumn{2}{|c|}{ USER ACCOUNT SECURITY } \\
\hline \multicolumn{2}{|c|}{$\begin{array}{l}\text { Legitimate user accounts are cften exploted by attackers to gain access to sensitive systems and hide their tracks. Strengthening user account security helps } \\
\text { protect against these attacks. }\end{array}$} \\
\hline \multicolumn{2}{|c|}{ This is part of SANS Critical Control 16: Account Monitoring and Control and many other security frameworks. } \\
\hline FAIIFD & Windows Password Complexity is Enabled \\
\hline FAIIFD & Minimum Windows Password Length Configured to be at Least 8 Characters \\
\hline FAIIFD & Windows Account Lockout Counter Configured to Wait at Least 15 Minutes Before Reset \\
\hline FAILEO & Windows Account Lockout Duration Configured to at Least 15 Minutes \\
\hline
\end{tabular}

Gambar 8 Windows 8 User Account Security

\section{4) Target Vulnerability Validation Techniques}

Target $V$ ulnerability $V$ alidation Techniques adalah bagaimana menggunakan informasi yang telah ditemukan dalam tahap sebelumnya (vulnerability scanning) dan mengeksplorasi potensi vulnerability tersebut bagi keamanan komputer. Dengan temuan vulnerability di atas akan dicoba melakukan penetration testing untuk semakin mengeksplorasi kelemahannya bagi keamanan komputer secara menyeluruh. Umunya pada tahap ini akan dilakukan penetration testing.

Dengan skenario pertama mesin satu adalah Kali Linux dan mesin ke dua adalah Windows 7 dan dilakukan penyusupan dengan metasploit maka Windows 7 tersebut tergolong memiliki vulnerability yang tinggi.

Langkah-lanngkah penyusupan dengan metasploit :

1. Luncurkan metasploit di terminal dengan perintah \#msfconsole

2. Gunakan modul Windows yang ada di metasploit \#use exploit/windows/browser/ms10_046_shortcut_icon_dllloader

3. Gunakan payload \#set payload windows/meterpreter/ reverse_tcp

4. Set IP server dan host mesin yang akan digunakan untuk melakukan metasploit \#set SRVHOST 192.168.10.100 dan \#set LHOST 192.168.10.100

5. Lalu luncurkan perintah \#exploit

6. Pada mesin korban, cukup buka browser dan hubungkan ke mesin Kali Linux, pada browser ketikkan bttp://192.168.10.100

7. Maka jika sudah, pada mesin Kali Linux akan memberikan informasi korban telah login ke sistem

8. Ketik perintah \#meterpreter $>$ session $-i 1$

9. Maka windows 7 sudah dalam kontrol 


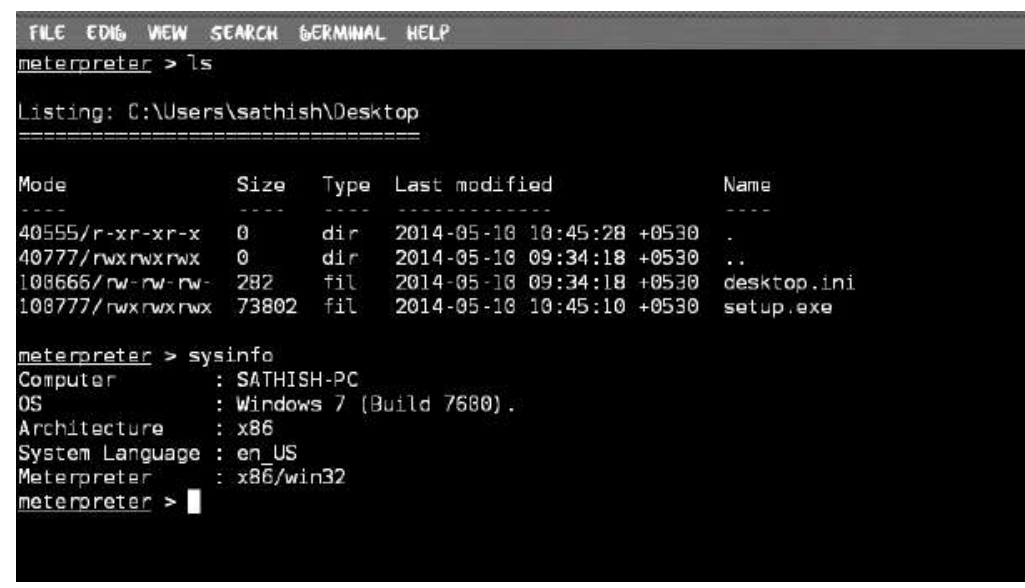

Gambar 9 Windows 7 Under Control

Dengan menggunakan teknik yang sama ternyata skenario ini tidak bisa dilakukan pada Windows 8. Hal ini dikarenakan adanya Windows Defender yang mampu mendeteksi penyusup yang akan masuk ke sistem.

\section{Kesimpulan dan Rekomendasi}

Berdasarkan analisis hasil penelitian dan pembahasan sebagaimana peneliti jabarkan analisis di atas, maka dapat ditarik beberapa kesimpulan yang merupakan kesimpulan dari jawaban rumusan masalah. Windows 7 sebaiknya menggunakan anti virus atau firewall pihak ke tiga atau mengunduh Miscrosoft Security Essensials untuk melindungi dari serangan melalui teknik penyusupan metasploit. Sedangkan untuk sistem operasi Windows 8 walaupun dengan adanya fitur Windows Defender namun jika tidak di update dengan regular serangan tetap dapat dilakukan dengan memanfaatkan vulnerability yang ada. Dari pengujian yang dilakukan peneliti dalam penelitian ini, maka perbandingan antara sistem operasi Windows 7 dan Windows 8 menghasilkan bahwa Windows 8 lebih aman dibandingkan Windows 7 dikarenakan adanya firur Windows Defender yang merupakan gabungan antara Windows Defender pada Windows 7 dan Miscrosoft Security Essensials.

Bagi para pengguna sistem operasi Windows 7 untuk meningkatkan keamanan sistem, disarankan untuk mengunduh dan menginstal anti virus pihak ke tiga dan untuk selalu meng-update sistemnya, sementara bagi para pengguna Windows 8 untuk menambah keamanan dapat juga menambahkan anti virus pihak ketiga disamping selalu mengupdate sistem secara regular. Untuk penelitian selanjutnya agar dapat diuji kemanan pada Windows 10 dengan membandingkannya juga dengan sistem sebelumnya atau dengan sistem operasi selain Windows, misalnya Linux. 


\section{Referensi}

[1] "Desktop Operating System Market Share", online https://www.netmarketshare.com/operatingsystem-market-share.aspx?qprid=10\&qpcustomd=0, diakases 27 April 2016

[2] Kusnadi, S.T., M.Eng.Sc., Kusworo Anindito, S.T.,M.T. (2008), “Sistem Operasi”. Penerbit Andi, Yogyakarta

[3] Gupta, Kalpana. Barkha Kakkar. Vivek Sen Saxena (2013), “A Comparative Study of Two Operating System: Windows 7 and Windows 8”. Scholars World- International Refereed Multidisiplinary Journal of Contemporary Research. ISSN 2319-5789

[4] Karnia, Rizky (2013), “Windows 8 Operating System Security Analysis”. Bina Nusantara University, Jakarta

[5] Stalling William. (2012), “Operating System, Internal and Design Principles, $7^{\text {th }}$ Edition.” Prentice Hall.

[6] Tanenbaum. Andrew.S (2008), "Modern Operating System, $3^{\text {rd }}$ Edition”. Pearson Education.Inc

[7] Nash, Mike (28 October 2008). "Windows 7 Unveiled Today at PDC 2008". Windows Team Blog. Microsoft. https://blogs.windows.com/windowsexperience/2008/10/28/windows-7unveiled-today-at-pdc-2008/ Diakses 28 April 2016

[8] LeBlanc, Brandon (28 October 2008). "How Libraries \& HomeGroup Work Together in Windows 7". Windows Team Blog. Microsoft. https://blogs.windows.com/windowsexperience/2008/10/28/how-libraries-homegroupwork-together-in-windows-7/ Diakses 28 April 2016

[9] Raharjo, Budi (2002), “Aspek Pengamanan dalan Dunia E-Commerce, IdCert, Jakarta.

[10] Karen Scarfone, Murugiah Souppaya, Amanda Cody, and Angela Orebaugh. Nist special publication 800-115: Technical guide to information security testing and assessment, 2008. 